\title{
Kebiasaan makan balita stunting pada masyarakat Suku Sasak: Tinjauan 1000 hari pertama kehidupan (HPK)
}

\author{
Dietary habit in stunting toddler in Sasak people: Observation of \\ 1000 first day of life
}

\author{
$\underline{L i n a ~ N u r b a i t i}^{1}$, Annis Catur Adi, Shrimarti R Devi, Timbuktu Harthana \\ Korespondensi: Fakultas Kedokteran Universitas Mataram. Jalan Pendidikan No 37 \\ Mataram Telepon : (0370)640874 \\ E-mail: betty herlin@yahoo.com
}

\begin{abstract}
The first 1000 days of a child's life is the most crucial period for child's cognitive and mental development. The lack of nutrition in the period would cause inter-generation shortness, known as stunting. Moreover, stunting could lead to brain cells development and increase the risk of degenerative disease. The phenomena was mostly found in Central Lombok with high pervelance of stunting in toddler. This research uses qualitative approach with phenomenology research design; conducted in Community Health Center (Pusat Kesehatan Masyarakat/Puskesmas) in Sengkol, District of Central Lombok. This article concludes that there are diatery habit in Sasak people which became predisposing factors to the occurrence of stunting to the children in Sasak. Those are the lack of animal protein intake, mistreatment of breast milk pattern giving which causes failure to fulfill nutrition standard, and there are myth-related belief that opposes the principal of nutrition fulfillment in children.
\end{abstract}

Key words: stunting, sasak people, breast milk, dietary habit

\begin{abstract}
Abstrak
Periode 1000 hari pertama kehidupan seorang anak merupakan periode yang sangat penting bagi pertumbuhan kognitif dan mental anak. Kekurangan gizi pada 1000 hari pertama akan berpengaruh pada kependekan anak intergenerasi, atau dikenal dengan stunting. Selain itu, stunting juga dapat mempengaruhi perkembangan sel otak dan meningkatkan potensi risiko penyakit degeneratif. Lombok Tengah merupakan wilayah dengan prevalensi stunting pada Balita yang tinggi. Riset ini dilakukan melalui pendekatan kualitatif dengan desain penelitian fenomenologi; dilakukan di wilayah kerja Puskesmas Sengkol, Kabupaten Lombok Tengah, NTB. Simpulan dari penelitian ini adalah terdapat kebiasaan pola makan yang diterapkan sehari-hari oleh masyarakat Suku Sasak yang menjadi faktor predisposisi munculnya stunting pada anak-anak Suku Sasak di lokasi penelitian antara lain: kurangnya asupan protein hewani, pemberian ASI kepada balita yang kurang tepat dan belum memenuhi standar gizi berimbang, serta adanya kepercayaan yang bertentangan dengan prinsip-prinsip gizi pada anak.
\end{abstract}

Kata kunci: stunting, suku sasak, ASI, pola makan

\section{Pendahuluan}

Indonesia adalah negara yang memiliki banyak suku. Nusa Tenggara Barat (NTB), merupakan salah satu provinsi yang terdiri dari beragam suku, di antaranya adalah Suku Sasak, Mbojo, dan Samawa. Suku Sasak merupakan suku terbesar yang terdapat di NTB. Adat istiadat dan kebudayaan yang sudah mengakar memberi pengaruh yang besar pada perilaku dan kebiasaan hidup mereka, termasuk kebiasaan makan dan pola makan sehari-hari. Jenis bahan dan menu makanan yang dikonsumsi, 
waktu makan, frekuensi makan, tujuan makan, hingga jenis bahan makanan yang ditabukan masyarakat Suku Sasak sangat dipengaruhi adat dan budayanya. Hal serupa diberlakukan kepada anak pada 1.000 hari pertama kehidupannya.

Periode 1.000 hari yang dimaksud adalah 270 hari selama kehamilan ibu, hingga 730 hari pada kehidupan pertama bayi yang dilahirkan. Periode ini merupakan periode sensitif dan sangat penting, sehingga disebut golden periode. Sebab, dampak yang dapat timbul ketika kebutuhan anak tidak terpenuhi akan bersifat permanen dan tidak dapat dikoreksi. Dampaknya tidak hanya pada pertumbuhan fisik, tapi juga pada perkembangan kognitif dan mental (Sulistyaningsih 2011). Oleh karena itu, asupan makanan bergizi dan pola makan yang tepat akan sangat mempengaruhi tumbuh kembang seorang anak dan generasi masa depan sebuah bangsa.

Salah satu dampak tidak terpenuhinya gizi pada 1.000 hari pertama kehidupan anak adalah stunting. Dampak jangka panjang stunting atau kependekan adalah terjadinya kependekan anak intergenerasi. Pada anak perempuan, dampaknya akan terlihat ketika dewasa atau hamil. Perempuan yang stunting berisiko lebih tinggi mengalami retardasi atau perlambatan pertumbuhan pada janinnya (intra uterine growth retardation/IUGR) serta melahirkan bayi dengan berat badan lahir rendah (BBLR) (Keefe et al. 2008). Tubuh yang pendek secara psikologis juga mempengaruhi self-esteem seorang anak dalam kehidupan sosialnya, terutama saat menginjak remaja.

Akibat stunting tidak hanya kependekan, tetapi juga mempengaruhi perkembangan sel otak, sehingga kemampuan kognitif dan kecerdasaanya menurun (Allen \% Gillespie 2001; Crookston 2010). Reaksi penyesuaian tubuh akibat kurangnya asupan gizi adalah peningkatan risiko penyakit degeneratif, seperti obesitas, diabetes, dan jantung koroner pada usia dewasa. Jika masalah stunting tidak diatasi, akan semakin banyak generasi muda Indonesia di masa depan yang pendek bahkan tidak berkualitas.

Pengertian stunting pada penelitian ini adalah status gizi yang didasarkan pada indeks panjang badan atau tinggi badan menurut umur (WHO 2006). Secara fisik, anak balita terlihat lebih pendek dibandingkan anak balita seumurannya. Dalam definisi lain, stunting adalah pertumbuhan linier yang gagal untuk mencapai potensi genetik, sebagai akibat dari pola makan yang buruk dan penyakit (ACC/SCN \& IFPRI 2000). Maka, stunting atau kependekan dapat diketahui bila balita diukur panjang atau tinggi badannya lalu dibandingkan dengan standar, hasilnya berada di bawah normal.

Saat ini, angka prevalensi stunting atau perawakan tubuh pendek pada anak-anak di Indonesia masih jauh dari standar WHO, yang menyaratkan 20 persen sebagai batas non public health problem untuk masalah stunting. Secara nasional, angka stunting anak-anak di Indonesia adalah 37,2 persen (Riskesdas 2013). Sebanyak 20 provinsi ternyata memiliki angka prevalensi kependekan di atas angka nasional. Provinsi NTB termasuk tiga provinsi dengan angka prevalensi stunting tertinggi, yaitu 45,3 persen, berada di bawah Nusa Tenggara Timur (51,7 persen) dan Sulawesi Barat (48 persen).

Data Riskesdas menunjukkan bahwa kependekan lebih banyak terjadi pada anak laki-laki dibandingkan anak perempuan. Selisih tinggi rata-rata anak laki-laki di Indonesia dengan tinggi anak laki-laki sesuai rujukan WHO adalah $12,5 \mathrm{~cm}$. Sementara selisih tinggi rata-rata tinggi anak perempuan lebih kecil, hanya adalah $9,8 \mathrm{~cm}$. Anak-anak yang tinggal di perkotaan cenderung lebih tinggi dibandingkan anak-anak di pedesaan. Selisih tinggi anak laki-laki di kota dan desa adalah 2,7 $\mathrm{cm}$, sedangkan pada anak perempuan hanya $1,7 \mathrm{~cm}$.

Berdasarkan Pemantauan Status Gizi 2011 menunjukkan bahwa angka kependekan di Kabupaten Lombok Tengah adalah 38,83 persen (Dinas Kesehatan Loteng 2011). Namun, dari penelitian sebelumnya di Kecamatan Pujut, Kabupaten Lombok Tengah, prevalensi stunting mencapai 84,8 persen. Sebanyak 31,7 persen anak-anak tergolong pendek, dan 53,1 persen tergolong sangat pendek (Nurbaiti \& Irawati 2011).

Masih tingginya masalah gizi di Lombok Tengah terutama tingginya prevalensi stunting pada balita, menjadikan latar belakang penelitian ini. Berdasarkan uraian tersebut, penulis tertarik untuk meneliti 
lebih jauh mengenai kebiasaan makan dan keragaman konsumsi pada balita stunting Suku Sasak terkait dengan asupan makanan dalam 1000 HPK.

\section{Metode Penelitian}

Riset ini dilakukan melalui pendekatan kualitatif dengan desain penelitian fenomenologi. Penelitian dilakukan di wilayah kerja Puskesmas Sengkol, Kecamatan Pujut, Kabupaten Lombok Tengah, NTB. Data diperoleh dari wawancara mendalam, observasi, dan diskusi kelompok terarah. Wawancara mendalam dilakukan kepada key informan yang terdiri dari empat orang, yaitu seorang tokoh agama (tuan guru), tokoh budaya, bidan senior, dan dukun beranak (belian). Data kualitatif yang dikumpulkan adalah informasi tentang filosofi masyarakat Suku Sasak tentang makanan, pola dan frekuensi makan, dan makanan yang ditabukan bagi anak-anak dan ibu hamil.

Observasi dan diskusi kelompok terarah dilakukan dengan mengamati kebiasaan makan yang terdiri dari pola konsumsi, frekuensi makan, kesukaan, dan makanan yang ditabukan. Observasi dilakukan pada empat keluarga yang memiliki balita di empat lokasi yang berbeda, sedangkan diskusi kelompok terarah dilakukan pada tiga kelompok, yang masing-masing kelompok terdiri dari enam-delapan orang ibu yang memiliki balita.

\section{Hasil Penelitian}

\section{Kebiasaan makan Suku Sasak}

Menurut orang Sasak, makanan adalah segala sesuatu yang dapat dimakan yang dapat mengenyangkan dan menyenangkan hati. Makanan pokok pada umumnya adalah nasi dan lauk pauk ("daun" dalam bahasa Lauk/Sengkol). Perbandingannya, jumlah nasi selalu lebih banyak dari pada lauk pauk. Ragam lauk pauk setiap kali makan pada umumnya hanya satu macam ditambah dengan sayur yang berkuah dengan sambal dan garam sebagai penambah rasa.

Dalam konsep makanan orang Sasak, bahan makanan yang dapat mengenyangkan dan menggemukkan hanyalah nasi. Lauk pauk dan sayur mayur hanya berfungsi sebagai penyedap dan pelancar. Konsep ini berlaku juga pada balita. Balita diberi makan agar kenyang, tidak terpikir oleh sebagian besar ibu/pengasuh mengenai susunan menu ataupun gizi (Hasil FGD pada tiga kelompok ibu yang memiliki balita, 21,23, 24 Maret 2014). Bagi ibu, nasi adalah makanan yang utama. Bila sudah ada nasi, kesehatan dan pertumbuhan orang pasti terjamin. Makan selain nasi dianggap belum makan, sekalipun sampai kenyang.

"...sak penting arak rasen dait besuh, uwah benasiq"

Artinya: yang penting ada rasa dan kenyang; kenyang yang penting sudah makan nasi.

(indepth interview, HLA, tokoh agama, 20 Maret 2014)

“...pokokn besebur, berase'

Artinya: yang penting berkuah dan berasa.

(indepth interview, L M, tokoh budaya, 22 Maret 2014 dan IS, dukun beranak, 28 Maret 2014)

Pernyataan di atas menekankan bahwa makan yang penting kenyang, rasanya enak dan yang penting berkuah, baik itu kuah yang berasa ataupun kuah sayur bening yang ditambahkan rasa sedap dengan tambahan sambal monte/jeruk purut.

\section{Nyampah, betengari, dan mangan kebian}

Berdasarkan hasil indepth interview dengan LM, tokoh budaya, sebelum dekade 80-an, orang Sasak yang pada umumnya petani mengenal dua kali makan besar dalam sehari yaitu mangan kelemaq dan 
mangan kebian. Sementara nyampah adalah makan pada saat matahari terbit, sebelum bekerja/beraktifitas. Nyampah berupa kopi dan kudapan seperti ketan atau umbi-umbian rebus atau jagung rebus.

Mangan kelemaq adalah makan makanan utama pada jam 9 pagi yang terdiri dari nasi, satu macam lauk dari hewani atau nabati dan atau satu macam sayur. Lauk dan sayur dimasak dengan bumbu lengkap (beragi). Mangan kebian adalah makan makanan utama sebelum matahari tenggelam (magrib) dengan menu yang sama dengan mangan kelemaq. Ibu (istri) memasak hanya satu kali dalam sehari pada pagi hari setelah nyampah dan untuk mangan kebian, sayur dan lauk dihangatkan kembali. Kebiasaan nyampah hanya dilakukan oleh laki-laki dewasa Suku Sasak. Sementara itu, perempuan, anak-anak, dan balita tidak pernah nyampah, mereka cukup mangan kelemaq dan mangan kebian.

Saat ini pola konsumsi Suku Sasak bergeser mengikuti pola umum yang ada di kebanyakan belahan dunia, terdiri dari nyampah, betengari dan mangan kebian. Nyampah yang dimaksud adalah mangan kelemaq seperti sebelum dekade 80-an, berupa makanan lengkap (nasi, satu macam lauk hewani atau nabati dan atau satu macam sayur) tetapi dimasak dengan bumbu sederhana (ndeqn beragi) pada jam 9 pagi atau bisa berupa kopi dan kudapan ringan atau umbi-umbian yang direbus (indepth interview, LM, tokoh budaya,). Sebagian besar masyarakat Suku Sasak tidak terbiasa untuk nyampah, jika nyampah dilakukan, menu yang biasa disajikan adalah nasi, telur ceplok/dadar dengan atau tanpa sambal; nasi, mie instan dengan atau tanpa telur (hasil FGD pada tiga kelompok ibu yang memiliki balita, 21,23, 24 Maret 2014).

Betengari (makan siang) adalah makan makanan utama pada siang hari di antara jam 11.00-13.00 yang terdiri dari nasi, satu macam lauk hewani atau nabati dan atau satu macam sayur. Mangan kebian (makan sore) adalah makan makanan utama pada sore hari jam 17.00-18.00 (sebelum maghrib) dengan menu yang sama pada saat betengari. Menu makan betengari dan mangan kebian dimasak sekitar jam 10.00 pagi menggunakan bumbu lengkap (beragi) (indepth interview, LM, tokoh budaya).

Sebagian besar pola konsumsi nyampah (sarapan) pada balita, ibu hamil maupun menyusui terdiri dari nasi, ditambah satu macam lauk seperti telur, tahu, tempe atau ikan. Sebagian besar pola konsumsi betengari (makan siang) dan mangan kebian (makan malam) adalah dengan komposisi menu yang terdiri dari nasi, ditambah satu macam lauk (hewani atau nabati), dan satu macam sayur.

Waktu nyampah sebagian besar pada pukul 07.00-09.00. Waktu betengari pada pukul 12.00-14.00. Waktu mangan kebian sebagian besar pada pukul 17.00-18.00. Sebagian besar masyarakat Suku Sasak terutama balita dan ibu hamil memiliki frekuensi makan 1-2 kali sehari. Sebagian lagi memiliki frekuensi makan 2-3 kali sehari. Jika makan 2 kali sehari, makan pagi dilakukan antara waktu makan pagi dan siang sekitar pukul 10.00-11.00 dan makan malam (mangan kebian) pada pukul 17.00-18.00.

Bahan makanan yang dikonsumsi harian oleh kebanyakan balita, ibu hamil, dan ibu menyusui di Suku Sasak adalah sayur dan tahu/tempe. Ikan dan buah dikonsumsi mingguan; daging dan ayam dikonsumsi bulanan; telur dikonsumsi harian ataupun mingguan; sedangkan hati ayam dan susu hampir tidak pernah dikonsumsi. Umumnya, alasan tidak mengkonsumsi daging, hati, ayam, dan susu adalah karena mahal. Alasan lainnya adalah akses penduduk ke pasar terlalu jauh sehingga jarang mengonsumsi buah, ikan, dan telur. Hampir sebagian besar balita tidak mengkonsumsi sayur karena alasan tidak suka.

Beberapa masyarakat Suku Sasak di lokasi penelitian malah lebih memilih menjual telur yang dihasilkan ayam-ayamnya untuk dibelikan bumbu, dari pada dikonsumsi atau diberikan untuk anakanaknya. Mereka lebih mementingkan rasa dari pada kecukupan gizi pada makanan yang disajikan. Kebiasaan ini sudah turun temurun dan terus berlanjut sampai sekarang. Hal ini juga karena didorong oleh pengetahuan dan keterampilan ibu-ibu mengolah bahan makanan yang sangat minim. Ibu-ibu lebih mendahulukan rasa, yang berasal dari bumbu seperti terasi, dari pada kandungan gizi pada menu makanan yang disajikan di rumahnya. 


\section{Tahapan makan balita}

Ibu menyusui anak sampai usia minimal 1,5 tahun dan kebanyakan 2 tahun atau lebih. Menurut masyarakat Suku Sasak di daerah penelitian, ASI masih mencukupi kebutuhan anak mereka sampai usia anak maksimal dua tahun, sehingga anak-anak cukup diberi makan dua kali sehari. Pola makan dua kali sehari ini sudah turun temurun dilakukan sejak zaman nenek moyang mereka tanpa ada penjelasan mengapa hal tersebut dilakukan.

Anak mulai diberi makanan pendamping ASI berupa bubur susu instan atau bubur tepung beras yang dimasak sendiri tanpa lauk pauk saat anak mulai berusia 7 atau 8 bulan. Bubur instan hanya diberikan dua kali sehari dengan porsi dua sendok makan atau $1 / 2$ sachet bubur instant kemasan praktis untuk sekali makan. Apabila ibu membuat bubur nasi sendiri, ibu tidak akan menambahkan lauk pauk atau sayuran, cukup dengan kuah sayur saja atau air garam. Hal ini dilakukan karena menganggap bahwa ASI sudah cukup memenuhi kebutuhan gizi anak sampai kapanpun anak mau menyusu.

Setelah usia balita 9 bulan ke atas, balita sudah mulai diberi nasi dengan lauk telur/ikan dengan kuah sayur bening atau nasi saja. Nasi diberikan untuk menggemukkan anak. Usia dua tahun ke atas, balita diberi makan sesuai makanan keluarga tapi tidak pedas. Jika ibu memasak makanan pedas, balita hanya diberi makanan tidak pedas yang ada semisal tahu/tempe/telur/ikan goreng saja atau cukup dengan nasi dan air garam. Sayur hanya kuahnya saja atau jika ada rata-rata hanya satu sendok teh.

Untuk anak usia dua tahun ke atas, sebagian besar masyarakat membiarkan anak mereka untuk jajan terutama pentol (bakso cilok terbuat dari tepung kanji dicampur sedikit daging dan campuran bumbu) dan makanan ringan yang dijual keliling desa atau di warung. Pengeluaran harian untuk jajanan tiap anak rata-rata Rp 5.000-Rp15.000/hari/anak. Jika anak sudah makan makanan ringan, jajanan, dan sebagainya dianggap sudah cukup untuk mengganjal perut. Fenomena ini disebabkan ibu tidak punya banyak waktu untuk mengasuh anak termasuk untuk memasak makanan khusus untuk balita akibat beban kerja ganda ibu. Anak dibiarkan memilih makanan yang disukai tanpa ada larangan.

\section{Budaya tabu makan pada tahap kehidupan}

Saat Hamil. Tabu makan menurut masyarakat Suku Sasak adalah pantangan makan tertentu yang tidak boleh dikonsumsi. Jika pantangan dilanggar akan berakibat buruk bagi kesehatan. Jenis makanan yang dipantang oleh ibu hamil masyarakat Suku Sasak adalah gurita, udang, cumi-cumi, kerang, ikan-ikanan terutama ikan hiu, jantung pisang, salak, nanas, duren dan biji-bijian/kacangkacangan yang keras.

Alasan mengapa makanan tersebut dipantangkan pada ibu hamil karena dikhawatirkan memberi dampak buruk bagi kesehatan ibu dan janinnya. Contoh pertama, jika ibu hamil mengonsumsi gurita, diyakini janin akan terbelit ari-ari ketika dilahirkan dan juga akan mengakibatkan penyakit gatal pada ibu dan janinnya. Kedua, jika ibu hamil mengonsumsi ikan hiu akan mengakibatkan janin sulit keluar dan akan terjadi perdarahan saat melahirkan.

Ketiga, jika ibu hamil mengonsumsi ikan akan mengakibatkan bau badan ibu dan janin dalam kandungan menjadi amis. Keempat, jika ibu hamil mengonsumsi udang dikhawatirkan anak yang dilahirkan akan bungkuk. Kelima, jika ibu hamil mengonsumsi jantung pisang akan mengakibatkan bentuk kepala bayi lonjong seperti jantung pisang.

Keenam, jika ibu hamil mengonsumsi salak akan menyebabkan ibu menjadi susah BAB dan terakhir, jika jika ibu hamil mengonsumsi durian dan nanas akan menyebabkan keguguran. Ibu hamil tidak diperbolehkan makan terlalu banyak agar janin dalam kandungannya tidak besar yang akan menyebabkan perdarahan dan kesulitan saat melahirkan (hasil FGD pada tiga kelompok ibu yang memiliki balita, 21,23, 24 Maret 2014). 
Sebagian besar ibu sebenarnya kurang percaya dengan pantangan tersebut tetapi ibu masih mematuhinya karena terpaksa, takut disalahkan dan melawan apa kata orang tua. Jika ibu hamil/menyusui ingin makan-makanan yang dipantang, dia diperbolehkan mengonsumsinya dalam porsi yang sedikit atau terbatas.Latar belakang pantangan atau tabu tersebut didasarkan pada kepercayaan agar ibu sehat, tidak mengalami kesulitan dan perdarahan pada waktu melahirkan dan agar bayinya tidak terlalu besar (hasil FGD tiga kelompok ibu yang memiliki balita, 21,23, 24 Maret 2014).

\begin{abstract}
"Nendeq mangan loek lalok, adekn sehat trus kanaq ndekn beleq elek dalem, serean beleq eleq duah, laon penoq darah saq sugul pas nganak lamun beleq eleq dalem tian ato bareh te operasi jarin"

Artinya: Ibu hamil tidak boleh terlalu banyak makan, agar ibu sehat dan bayi di dalam kandungannya tidak besar (lebih dari $3 \mathrm{~kg}$ ), lebih baik bayi besar di luar (setelah lahir), jika terlalu besar akan terjadi perdarahan ketika melahirkan atau ada kemungkinan di operasi.

(indepth interview IS, dukun beranak, 28 Maret 2014).
\end{abstract}

Saat Menyusui. Sedangkan pantangan/tabu makan pada ibu menyusui adalah makanan pedas, pisang, labu dan ikan. Jika ibu menyusui makan makanan pedas dipercaya oleh masyarakat Suku Sasak akan mengakibatkan bayi yang disusui mengalami diare, dan jiak makan pisang maka bayi akan menderita sariawan. Sementara memakan labu diyakini akan menyebabkan rahim sakit. Makan ikan-ikanan akan menyebabkan bayi gatal dan bau badannya amis (indepth interview, BM, bidan senior, 26 Maret 2014).

Ibu Suku Sasak yang baru melahirkan atau operasi hanya boleh makan tahu dan tempe tanpa garam (nganyep), dilarang banyak makan dan minum, terutama makan makanan yang amis (seperti makanan laut, telur, daging, dan terasi). Makanan harus disangrai/dibakar. Setelah maghrib, ibu sama sekali tidak diperbolehkan makan. Larangan makan ini didasari keyakinan bahwa makanan yang dilarang tersebut dapat membahayakan kesehatan ibu, karena luka bekas operasi atau luka di jalan lahir setelah melahirkan akan sulit sembuh atau sulit kering (indepth interview, BM, bidan senior, 26 Maret 2014; IS, dukun beranak, 28 Maret 2014).

Balita. Pantangan makan untuk anak terutama jika anak sakit. Pantangan tidak berlaku untuk anak yang sehat(hasil FGD pada tiga kelompok ibu yang memiliki balita, 21,23, 24 Maret 2014). Pantangan makan pada balita sakit adalah pisang, telur, ikan laut, ayam, dan makanan amis lainnya. Jika pantangan ini dilanggar, penyakit pada anak balita akan semakin parah. Contohnya, jika anak balita demam, dilarang makan pisang karena akan menyebabkan demamnya tidak turun. Jika anak batuk, pilek, demam, ataupun gatal-gatal akibat penyakit kulit, dilarang makan telur, ikan laut, ayam, dan makanan amis lainnya karena akan menyebabkan penyakitnya bertambah parah (indepth interview, BM, bidan senior, 26 Maret 2014; IS, dukun beranak, 28 Maret 2014).

\title{
Pola asuh dan asuhan makan Suku Sasak
}

Berdasarkan hasil penelitian, masyarakat Suku Sasak menganggap semua hal sepenuhnya diatur oleh Tuhan. Apapun yang dilakukan oleh manusia adalah kehendak Sang Pencipta. Manusia hanya menjalankan kehidupan menurut ketentuan yang telah ditetapkan oleh Tuhan. Demikian juga pada saat melakukan pola asuh pada anak balita. Pernyataan ini menunjukkan sikap pasrah masyarakat Suku Sasak terhadap segala sesuatu hal yang berlaku di kehidupan ini. Berikut contoh kuotasi pernyataan tersebut:

"...W Wah mule iye ntan tejab isiq Neneq"

Artinya: memang sudah diatur sepenuhnya oleh Tuhan.

(indept interview dengan HLA, tokoh agama).

Berdasarkan hasil observasi, sebagian besar ayah tidak terlibat langsung dalam pengasuhan balita. Pola asuh diserahkan sepenuhnya kepada ibu. Meskipun ibu diajak berunding di rumah dan berhak 
bicara, tetapi pengambilan dan penetapan keputusan didominasi oleh ayah. Ibu akan menunggu perintah dari ayah. Ketika pemahaman dan pengetahuan ayah tidak cukup memadai, ayah hanya memerintah saja menurut pendapatnya atau menyerahkan kembali ke istri untuk ditanyakan ke orang tuanya.

Ibu memiliki posisi tawar yang rendah dalam membuat keputusan terlebih lagi didukung dengan pendidikan yang rendah. Apapun yang diperintah oleh ayah akan dituruti oleh ibu. Pembagian tugas dalam keluarga sangat memberatkan ibu. Ibu mengerjakan semua pekerjaan rumah tangga dan sebagian besar ibu juga bekerja untuk membantu perekonomian keluarga. Sementara ayah hanya bertugas mencari nafkah.

\section{Cara makan}

Sebagian besar balita makan memakai tangan atau disuapi dengan tangan ibu/pengasuh tanpa perlu mencuci tangan sebelumnya. Ibu menyuapi dan menemani makan anak balita mereka sambil melakukan aktivitas sosial lainnya atau kegiatan rumah tangga lainnya. Biasanya anak diberi makan di halaman rumah, di pinggir jalan, atau sambil jalan-jalan menghampiri tetangga atau anggota keluarga lainnya yang tinggal berdekatan.

Umumnya, kebiasaan makan masyarakat Suku Sasak tidak di atas meja makan. Mereka makan di dalam rumah, beralas tikar, dan makan sambil duduk bersila atau lesesahan. Makan menggunakan tangan, dengan satu mangkok air sebagai pencuci tangan keseluruhan anggota keluarga yang makan bersama saat itu. Biasanya ibu menunggu ayah dan anggota keluarga lainnya selesai makan baru ibu memulai makan. Hal ini tidak berlaku pada ibu menyusui, karena ibu merasa mudah lapar, jika terasa lapar, ibu akan langsung makan tanpa menunggu ayah.

\section{Simpulan}

Stunting merupakan keadaan yang ditimbulkan akibat kekurangan nutrisi (malnutrisi). Kejadian malnutrisi tidak hanya disebabkan kekurangan zat gizi makro, tetapi juga kekurangan zat gizi mikro. Keadaan ini dapat terlihat ketika anak memasuki umur 2 tahun, ciri fisik tinggi badannya terlihat lebih pedek dari anak seumurannya. Ini merupakan keadaan kekurangan nutrisi yang sangat kronis pada anak. Penyebab stunting terjadi sejak masa kandungan, karena tidak mendapatkan gizi yang tepat untuk pertumbuhan janin. Asupan makanan yang masuk ke dalam tubuh sang ibu, kadang tak berdasarkan gizi seimbang yang diperlukan tubuh (Wibowo 2012).

Berdasarkan kebiasaan pola makan yang diterapkan sehari-hari oleh masyarakat Suku Sasak, terdapat beberapa kebiasaan yang menjadi faktor predisposisi munculnya stunting pada anak-anak Suku Sasak di lokasi penelitian. Pertama, keluarga Suku Sasak sangat jarang memberi asupan protein hewani kepada anak balitanya. Meski mereka mampu (penghasilannya cukup), orang Sasak cenderung tidak menyiapkan menu makanan yang beragam dan banyak protein hewani. Mereka lebih memilih menyajikan makanan yang kaya bumbu. Bagi mereka, makanan dengan bumbu lebih penting dari pada makanan yang kaya protein.

Balita jarang mengonsumsi sayur yang beragam, dan jumlah yang dikonsumsi sangat sedikit. Sayur yang dimaksud pun hanya berupa kuah sayur, bukan sayurannya. Akibatnya, anak-anak Suku Sasak tidak hanya defisit zat gizi makro, tetapi juga zat gizi mikro (vitamin dan mineral). Defisiensi energi, zat makro (karbohidrat) maupun mikro terjadi pada kelompok balita stunting maupun yang tidak stunting.

Kedua, pemberian ASI kepada balita yang kurang tepat dan salah persepsi. Menurut sebagian besar masyarakat Suku Sasak di wilayah penelitian, ASI adalah segalanya bagi anak usia 0-24 bulan, dan ASI dianggap mencukupi kebutuhan gizi anak. Seorang ibu Suku Sasak, rata-rata menyusui balitanya sampai usia minimal 1,5 tahun dan kebanyakan 2 tahun atau lebih. Mereka menganggap ASI cukup 
memenuhi kebutuhan gizi anak sampai kapanpun anak mau menyusu, bahkan menganggap ASI sebagai makanan utama sampai anaknya berusia 2 tahun. Sikap ini menunjukkan suatu bentuk ketaatan masyarakat Suku Sasak pada aturan agama yang menganjurkan pemberian ASI hingga usia 2 tahun.

Di satu sisi, pemberian ASI lebih dari 6 bulan adalah hal positif pada masyarakat Suku Sasak. Sebab, pada penelitian sebelumnya, seperti di buku Gizi Kesehatan Masyarakat (Gibney 2009), sejumlah penelitian menunjukkan bahwa kepercayaan dan sikap mendasar ibu meyakini ASI yang dihasilkannya tidak cukup dan berkualitas buruk, menyebabkan ibu tidak memberikan ASI eksklusif kepada bayinya selama 6 bulan pertama.

Sayangnya, keyakinan mereka tidak diikuti dengan pengetahuan bahwa setelah usia 6 bulan, ASI hanya dapat mencukupi sekitar 60-70\% kebutuhan gizi sehingga bayi mulai membutuhkan makanan pendamping ASI (MP-ASI). Balita sampai usia 2 tahun memang tetap perlu mendapatkan ASI, tapi harus diimbangi dengan asupan MP ASI untuk memenuhi kebutuhann gizi anak demi tumbuh kembang yang optimal (Depkes RI 2006).

Ketiga, pemberian MP ASI yang belum memenuhi standar gizi berimbang. Kebanyakan, balita Suku Sasak mulai dikenalkan MP ASI usia 7 atau 8 bulan. Sikap ini sesuai dengan anjuran MP ASI Depkes. Namun, menurut sebagian besar ibu, MP ASI hanya sebagai pelengkap ASI sehingga kualitas dan kuantitasnya,termasuk frekuensi dan jadwal pemberiannya tidak sesuai anjuran yang ditetapkan Depkes. Balita pada umumnya mengonsumsi bubur nasi tanpa lauk pauk (bubur kosong), cukup dengan kuah sayur saja atau air garam.

MP ASI tidak diberikan sesuai anjuran Depkes, baik secara kualitas maupun kuantitas oleh sebagian besar masyarakat Suku Sasak di Kecamatan Sengkol. Berdasarkan hasil FGD, alasan sebagian besar ibu tidak memberi MP ASI sesuai anjuran karena faktor ketidaktahuan, repot, malas, dan mengikuti kebiasaan nenek moyang mereka tanpa mengetahui alasan atau penyebabnya. Karena ASI dianggap sudah cukup bagi balita, maka mereka hanya memberi makan dua kali sehari kepada balitanya. Pola makan dua kali sehari ini sudah turun temurun dilakukan sejak zaman nenek moyang.

Keempat adalah tabu makanan yang melarang ibu hamil dan menyusui mengonsumsi beberapa bahan makanan kaya protein, serat, dan nutrisi. Kepercayaan yang bertentangan dengan prinsip-prinsip gizi ini masih dipraktikkan. Ikan dan cumi, yang tabu bagi ibu hamil, sebenarnya bahan makanan tinggi protein dan zinc yang sangat baik dalam pembentukan tulang panjang dan peningkatan daya tahan tubuh.

Demikian juga dengan buah-buahan yang dilarang dikonsumsi ibu hamil/menyusui sebenarnya sumber vitamin, mineral, dan serat, yang berfungsi membantu proses metabolisme tubuh. Bahkan, anak sakit dilarang makan telur, ayam, dan ikan laut, yang sebenarnya sumber protein hewani untuk meningkatkan status gizi anak ketika sakit. Apabila praktik tabu yang tidak tepat ini berlanjut, nantinya akan dapat merugikan status gizi, khususnya pada anak balita sakit, ibu hamil dan menyusui.

Kelima, yang terakhir, adalah pola asuh permisif dan sistem patrilineal yang berlaku di Suku Sasak. Apapun permintaan anak akan dituruti, dan tidak ada larangan atau aturan terutama dalam hal makan sehingga anak dibiarkan jajan makanan tidak bergizi asalkan anak senang dan kenyang. Jadwal makan anak juga tidak teratur. Pola asuh ini memberikan pengawasan yang sangat longgar pada anak.

Gambaran sistem patrilineal dan kepatuhan masyarakat Suku Sasak terhadap aturan agama sangat kuat, salah satunya yang menyatakan bahwa laki-laki adalah imam atau pemimpin wajib ditaati. Akan tetapi, banyak suami dan laki-laki dewasa Suku Sasak yang tidak memahami tentang pola asuh yang baik bagi balita, termasuk nutrisi yang tepat bagi anaknya. Di satu sisi, ibu-ibu Suku Sasak cenderung menunggu dan menuruti apapun keputusan suaminya untuk memberikan makanan kepada anakanaknya. 


\section{Daftar Pustaka}

ACC/SCN \& International Food Policy Research Institute (IFPRI) (2000) "4th Report on the World Nutrition Situation throughout the Life Cycle". Geneva: ACC/SCN in Collaboration with IFPRI.

Allen HL, Gillespie S (2001) What Works? A review of the efficacy and effectiveness of nutrition interventions. Genewa: United nations administrative committee on coordination sub-committe on nutrition $(\mathrm{ACC} / \mathrm{SCN})$.

Crookston BT, Penny ME, Aldes SC, Dickerson TT, Merril RM, Stanford JB, Porucznik CA, Dearden KA (2010) Children who recover from early stunting and children who are not stunted demonstrate similar levels of cognition. American society for nutrition. The Journal of Nutrition, 140(11):1996-2001.

Depkes RI (2000) Gerakan partipasif penyelamatan ibu hamil, menyusui dan bayi. Jakarta: Depkes RI.

Depkes RI (2006) Pedoman umum pemberian makanan pendamping air susu ibu lokal. Jakarta: Depkes RI.

Dinas Kesehatan Lombok Tengah (2011) Pemantauan status gizi: profil dinas kesehatan Lombok Tengah. Praya: Dinas Kesehatan Lombok Tengah.

Keefe CJL, Couch SC, Philipson E (2008) Handbook of nutrition and pregnancy. USA: Humana Press.

Nurbaiti L, Irawati D (2011) Profil status gizi balita bawah garis merah di wilayah kerja puskesmas Sengkol, Kecamatan Pujut, Kabupaten Lombok Tengah. The 7th Asia Pacific Conference on Clinical Nutrition (7th APCCN 2011) Bangkok.

Riskesdas (2013) Status gizi di NTB. Jakarta: Kementerian Kesehatan Republik Indonesia.

Sulistyaningsih H (2011) Gizi untuk kesehatan ibu dan anak. Yogyakarta: Graha Ilmu.

WHO (2006) Physical status: the use and interpretation of anthropometry. Geneva: WHO.

Wibowo N (2012) Pemenuhan gizi sebelum dan selama kehamilan berpengaruh pada kesehatan anak jangka panjang. Simposium "The Importance of Early Life Nutrition" Jakarta, Indonesia, 09 September 2012. http://nutricia.co.id/wp-content/uploads/2013/01/The-Importance-of-Early-LifeNutrition-OBGYN-Symposium-Press-Release. 